resolution was adopted in the following terms: "to request the council to consider by what means the Association, within the framework of its constitution, may assist towards a better adjustment between the advance of science and social progress, with a view to further discussion at the Aberdeen meeting". The new members of council are Prof. F. Aveling, Prof. R. N. Rudmose Brown, Prof. F. Balfour-Browne, Prof. G. W. Howe and Dr. J. A. Venn. The report of the council announces that the Seismology Committee of the Association is a prospective beneficiary in the sum of $£ 1,000$ under the will of Dr. J. E. Crombie, and that the late Mr. Bernard Hobson bequeathed $£ 1,000$ to be invested and the proceeds to be devoted annually to the "promoting of definite geological research". The Pilgrim Trust has promised the Association $£ 150$ a year for five years towards the maintenance of Down House. Invitations have been accepted to hold meetings of the Association at Norwich (1935), Blackpool (1936) and Nottingham (1937).

\section{A Ten-Year Plan for Industrial Research}

IF planning ahead in industry is necessary for national and international well-being and Democratic America, Fascist Italy, and Soviet Russia hold that it is-it is equally desirable for industrial research. The financing of scientific and industrial research in Great Britain has been marked by alternating gusts of national generosity and national parsimony, thus precluding the possibility of progressing on an even keel by laying down settled plans of research for more than a year ahead. During the decade 1930-40, the main avowed objective of the Forestry Commission was the planting of 353,000 acres of forest, for which a continuous supply of nursery stock had to be arranged in advance. In 1931 the programme was curtailed shortly after recovering from its birth pangs. This curtailment has resulted in an absolute loss-and waste-of $£ 50,000$ which had been invested in young trees which could not be planted out or sold; and this in the sacred name of 'economy'!

ON March 1, 1932, Great Britain was transformed by a stroke of the pen from a free trade to a protected community. That is to say, its industries became protected, but without any effective provision that the consuming public should also be protected by ensuring that the industrialists conducted their concerns in the most efficient and economic manner. Had a compulsory levy been made on our protected industries for the purpose of financing industrial research so as to render them better able to compete with other countries-and to produce for the home market at a reduced costor had a percentage of the resultant tariff revenue been earmarked for this purpose-say for a term of ten years-our statesmen would have shown greater vision. It is not too late, even now, for the Government to legislate on these lines; and a joint committee is being constituted by the British Science Guild and the Association of Scientific Workers to explore the subject and to formulate a scheme for presentation to the Government.

\section{Recent West Indian Hurricanes}

Reports of widespread damage and loss of life in Cuba and neighbouring islands, and in Mexico, Texas and Florida, during the first few days of September, due to West Indian hurricanes, suggest very exceptional storm activity even for the month which on an average provides the greatest number of hurricanes in those regions. The reported number of deaths on September 1 in Cuba alone had reached 150 by September 5, with more than 1,000 people more or less seriously injured. The storm that did the damage in Cuba appears to have been moving due west at that time, and to have passed on to reach Texas on September 4 without having lost much of its intensity. Another storm followed quickly along a more northerly path and was most destructive in the northernmost islands of the Bahamas and on the east coast of Florida. Its path appears to have been almost exactly the mean path for September hurricanes. Florida was reached on September 4. If the statement appoaring in the Times of September 6 is correct that destructive winds affecting the east coast of Mexico on the same date were due to two further tropical cyclones, then no fewer than four storm centres were reaching the Gulf Coast and Florida on the same date, which is remarkable soeing that the average number for the whole month is only a little more than one, even when hurricanes of less violence than the two most northerly of those just described are counted. A noteworthy feature of the Cuban storm was that at Cardenas, to the east of Havana, the wind-reported to have blown with a speed of 120 miles an hourdrove the sea inland no less than eight miles according to a detailed account that appeared some days after the disaster.

\section{Memorial to Jouffroy d'Abbans}

ON August 28 a memorial plaque was unveiled in the fortress of Sainte-Marguerite, Ile les Lerins, near Cannes, to Claude François Dorothée, Marquis de Jouffroy d'Abbans, the French infantry officer who, one hundred and fifty years ago, made a successful experiment with a steam-boat on the River Saône, near Lyons. The ceremony was attended by a naval guard of honour, and the Comte de Jouffroy d'Abbans, a descendant of the inventor, was present. Jouffroy was born in 1751 at Rochesur-Rognon, Haute Marne, and at the age of twentyone years joined the army. A visit to Paris stimulated his interest in the steam-engine and in 1776 he endeavoured to drive a boat by steam on the River Doubs. Of the construction of this, or of his boat of 1783, few details are known, and no development resulted from either of his experiments. Like all the earliest pioneers of the steam-boat, he found the problem of steam propulsion a very complicated one. That he did not continue his experiments was probably due to the outbreak of the Revolution, which caused him to emigrate, and he was absent from France for ten years. He still, however, retained his interest in the matter and in 1816 was connected with a company which placed the steam-boat Charles 